\title{
A Nameless but Active Religion: An Anthropologist's View of Local Religion in Hong Kong and Macau*
}

\author{
Tik-sang Liu
}

\begin{abstract}
Tik-sang Liu examines local religious practices in Hong Kong and Macau. He states that these constitute the foundation of local social organizations; they are the means with which local society is organized, local people are mobilized, communal activities are co-ordinated and people are prepared for their various stages in life.
\end{abstract}

In Hong Kong and Macau, people regularly organize temple festivals to celebrate the birthdays of their patron deities. People also regularly visit temples seeking the deities' blessings. A temple visit may be to ask for assistance when believers are facing difficulties or when they have health problems. Often people visit various patron deities, returning frequently until the problems are resolved. In order to communicate with the supernatural beings, people perform their own private rituals in temples, at ritual sites or in front of their own domestic altars. Interestingly, however, there is no agreed-upon name for these religious activities; some would even argue that they have no religious beliefs. Many people refer to their religious practices as "worshipping deities" (baishen) or "superstition" (mixin). Although people are aware of the negative implication of the word "superstition," they claim that it is the only known term to describe their religious practices. Some name their religious activities Buddhism or Daoism, as similar elements can be found in formal Buddhist or Daoist rituals. Professional Daoist priests or Buddhist monks and nuns are always hired to perform life cycle and communal rituals. To ordinary people, there is no clear boundary between Buddhism, Daoism and local religious practices.

In Hong Kong, there is no specific government office for religious affairs. In the government's view, Buddhism and Daoism are defined as "traditional Chinese religions." The deities in Chinese temples are considered either Buddhist or Daoist, while traditional festivals are defined as

* I would like to thank Kenneth Dean, Paul R. Katz and Daniel L. Overmyer for helpful comments on this article. I am particularly grateful to James L. Watson and Rubie S. Watson for their teaching and unfailing support. Fieldwork in Hong Kong's New Territories in 1990-91 was supported by a grant from the Joint Committee on Chinese Studies of the American Council of Learned Society and the Social Science Research Council. Further research in Macau and Hong Kong's New Territories in 2001 was made possible by a Direct Allocation Grant from the Hong Kong University of Science and Technology.

(C) The China Quarterly, 2003 
the practices of Chinese custom. Local religion is not an administrative category for the government. ${ }^{1}$

As for Hong Kong's local religion, there is no Hong Kong-wide organization or scripture accepted by all practitioners. However, local religion is very important to many Hong Kong people, is expressed in many different forms and plays an integral part in the practitioners' daily lives. People carry out ancestral worship at home, in ancestral halls or at the graves of their ancestors. People worship different deities, and participate in deity birthday festivals, communal Jiao festivals and Hungry Ghost festivals. Hong Kong residents try to locate their settlements, houses and ancestral graves according to the principles of geomancy, or fengshui. ${ }^{2}$

It is common to see local and individual variations in the celebration of the same festival as local religious activities are organized by local leaders with participants coming from diverse social backgrounds. The forms of religious expression are determined by local traditions, leadership and the availability of financial resources. Although lacking a unifying institution, local religion makes good use of elements coming from other religions and socio-cultural institutions. Hong Kong local religion is a flexible and highly adaptable cultural institution.

Religion is any human behaviour that relates humans to the supernatural world. Religion includes not only the ritual practices and organization, but also gives people a way to understand their world and the universe. People organize themselves as they organize religious activities; religion also explains for people the implications of their past, present and future. Anthropologists are interested in people's religious behaviour and thoughts. ${ }^{3}$

Many studies show that Chinese local religion operates in a passive mode. Based on his studies in Taiwan, Wolf argues that local religion is a reflection of people's conception of their social reality. The Chinese pantheon of deities is a mirror image of the imperial bureaucratic relations, while the ancestors and ghosts are a projection of the Chinese patrilineal kinship system. ${ }^{4}$

Anthropological studies of Hong Kong local religion show that local religious activities play an active role in ordinary people's social and daily life. Ward's study of Cantonese opera performances as part of temple festivals reveals that the content of the opera reflects people's view of the cosmos, and that the performance of the opera itself is also

1. Hong Kong Government, Hong Kong 2001 (Hong Kong: Information Services Department, Hong Kong Special Administrative Region Government, 2002), pp. 393-98.

2. See Maurice Freedman, "Chinese geomancy: some observations in Hong Kong," in William Skinner (selected and introduced), The Study of Chinese Society: Essays by Maurice Freedman (Stanford: Stanford University Press, 1979), pp. 189-211.

3. See Clifford Geertz, "Religion as a cultural system, in his The Interpretation of Cultures (New York: Basic Books, 1973), pp. 87-125; Andrew B. Kipnis, "The flourishing of religion in post-Mao China and the anthropological category of religion," Australian Journal of Anthropology, Vol. 12, No. 1 (2001), pp. 32-46.

4. Arthur P. Wolf, "Gods, ghosts, and ancestors," in Arthur P. Wolf (ed.), Religion and Ritual in Chinese Society (Stanford: Stanford University Press, 1974), pp. 131-182. 
an organized institution. The opera troupe operates according to strict religious tenets; it is an offering to the deity and a ritual to expel evil spirits $^{5}$ as well as a marker to reinforce (sub)ethnic identity. ${ }^{6}$ Potter's study of a group séance held by three shamans in Ping Shan demonstrates that shamanism functions as a means of local social control. The women involved, both dead and alive, none of whom had any formal status in local politics, attempted, with the aid of malevolent ghosts, to influence the rich and successful men in the community. ${ }^{7}$ After conducting a study in Ha Tsuen, Rubie Watson argues that grave rites performed by the Tang in Hong Kong's New Territories are ways of staging political and status conflicts, an opportunity for the Tang to claim their new political status. ${ }^{8}$ James Watson illustrates that people in the New Territories have successfully altered the functions of one of their local religious activities, the Jiao festival, from a parade defining territory to a ritual presentation expressing their wealth and status. Furthermore, social and political order are of a real concern to the local dominant powers and to the state. The powerful lineages demand that the subordinate villagers participate in religious activities as a show of loyalty, whereas the state officials are concerned with orthopraxy, the correct forms of religious activities. When religious activities are arranged in the proper way, religious belief is not a problematic issue for the local powers and for the state. ${ }^{9}$

\section{A Religion With No Political Boundary}

Hong Kong is an immigrant society with a large section of its population coming from South China, especially from the neighbouring Zhu (Pearl) River Delta area. Most of these immigrants arrived after 1949, at the time of the Great Leap Forward, or the Cultural Revolution. Hong Kong shares local religious activities and cultural traditions with neighbouring communities in the South China region, although there are always local variations. Many temples and ancestral halls in China have

5. Barbara E. Ward, "Not merely players: drama, art and ritual in traditional China," Man, Vol. 14, No. 1 (1979), pp. 18-39.

6. Barbara E. Ward, "Regional operas and their audiences: evidence from Hong Kong," in David Johnson, Andrew J. Nathan and Evelyn S. Rawski (eds.), Popular Culture in Late Imperial China (Berkeley: University of California Press, 1985), pp. 161-187; Chi-cheung Choi's study of the annual Jiao festival in Cheung Chau demonstrates that the festival consistently reinforces the social boundaries among various (sub)ethnic groups on the island. "Reinforcing ethnicity: the Jiao Festival in Cheung Chau," in David Faure and Helen Siu (eds.), Down to Earth: The Territorial Bond in South China (Stanford: Stanford University Press, 1995), pp. 104-122.

7. Jack M. Potter, "Cantonese shamanism," in Wolf, Religion and Ritual in Chinese Society, pp. 207-232.

8. Rubie S. Watson, "Remembering the dead: graves and politics in southeastern China," in James Watson and Evelyn Rawski (eds.), Death Ritual in Late Imperial and Modern China (Berkeley: University of California Press, 1988), pp. 203-227.

9. James L. Watson, "Fighting with operas: processionals, politics, and the spectre of violence in rural Hong Kong," in David Parkin, Lionel Caplan and Humphrey Fisher (eds.), The Politics of Cultural Performance: Essays in Honour of Abner Cohen (London: Berghahn Books, 1996), pp. 145-159; see also his "The structure of Chinese funerary rites: elementary forms, ritual sequence, and the primacy of performance," in Watson and Rawski, Death Ritual in Late Imperial and Modern China, pp. 3-19. 
been demolished over the last few decades; local religious activities have been attacked and banned, and in general have suffered from strong political suppression. Fortunately, local religious activities were allowed in Hong Kong and Macau, ${ }^{10}$ as they pose no threat to the ruling colonial governments. There are religious exchanges between Hong Kong and Macau; for example, Hong Kong opera troupes are often hired to perform in temple festivals in Macau. My research on the western coast of Hong Kong $^{11}$ shows that there are constant exchanges between these two places, especially among fisherfolk who make their living at the mouth of the Zhu River estuary. The fisherfolk participate in temple festivals and religious events in both places, as a result of their mobility from their fishing activities.

The fisherfolk in Hong Kong's Tai O and in Macau worship Immortal Zhu (Zhudaxian) who was a deity from Pinghai, a fishing port 80 kilometres east of Hong Kong, along the South China coast. Those in Macau celebrate the deity's birthday in the first lunar month, ${ }^{12}$ while in Hong Kong they celebrate the festival two months later. Both festivals follow the form of a Jiao festival, which pacifies the wandering ghosts near and in the water. Some of the fisherfolk continued participating in the festival in Macau even after they settled in Hong Kong, but others switched to the festival in Tai $\mathrm{O}^{13}$

Hong Kong and Macau were hubs of local religious activities when "feudalistic and superstitious practices" were being eliminated on the mainland. ${ }^{14}$ It is a mistake, however, to think that the two colonies have preserved the original religious activities, as these have been modified according to the colonial context. ${ }^{15}$ It is fascinating to observe how these

10. For the historical development of temples in Macau, see Jonathan Porter, Macau: The Imaginary City: Culture and Society, 1557 to the Present (Boulder: Westview Press, 1996), pp. 161-186; Keith G. Stevens conducted a comprehensive study of 450 temples in Hong Kong and Macau. Although he divides all the temples into the categories of Buddhist, Confucian, Daoist and folk religion, temples in the two colonies share no major geographical distinctions. "Chinese monasteries, temples, shrines and altars in Hong Kong and Macau," Journal of the Hong Kong Branch of the Royal Asiatic Society, Vol. 20 (1980), pp. 1-33d.

11. See Tik-sang Liu, "Becoming marginal: a fluid community and shamanism in the Pearl River Delta of South China," PhD dissertation, UMI, Ann Arbor 1995; Liao Disheng (Tik-sang Liu) and Zhang Zhaohe (Siu-woo Cheung), Da'ao: cong yugang dao dongfang Weinisi (Tai O: From a Fishing Village to "Oriental Venice”) (Hong Kong: Joint Publishing (HK) Co. Ltd., forthcoming).

12. Maritime Museum, Da Jiu Festival of Macao's Fishing Community and the Cult of Chu Tai Sin (Macau: Maritime Museum, Maritime Administration of the Macao Special Administrative Region, 2001).

13. Chen Yande, "Cong Aomen minsu kan dangdi jumin de Mazu chongbai" ("The folklore of local Mazu cult in Macau"), in Xu Xiaowang and Chen Yande (eds.), Aomen Mazu wenhua yanjiu (The Study of Mazu Culture in Macau) (Macau: Aomen jijinhui, 1998), p. 130; Liao and Zhang, Tai $O$.

14. See Anita Chan, Richard Madsen and Jonathan Unger, Chen Village: The Recent History of a Peasant Community in Mao's China (Berkeley: University of California Press, 1984), pp. 87-90.

15. See Liao Disheng (Tik-sang Liu), "You lianxiang miaoyu dao difang wenhua: Xianggang Xinjie Tianhou dan de difang zhengzhi yiyi" ("From an alliance temple to a local cultural symbol: the local political meaning of Tian Hou Cult in Hong Kong's New Territories"), in Lin Meirong, Zhang Xun and Cai Xianghui (eds.), Mazu xinyang di fazhan 
local religious elements have been reintroduced to the mainland since China's gradual opening in the early 1980s. ${ }^{16}$

\section{The Supernatural World and Supernatural Powers}

Practitioners of local religion in Hong Kong and Macau believe that there are many different deities residing in the supernatural world, all under the leadership of a supreme deity, the Jade Emperor. Guandi (God of War), Beidi (God of the North), Tian Hou (Empress of Heaven), and Hongsheng (God of the South Sea) are common gods of the middle rank, while Earth Gods are on the lowest level. As Wolf suggests, the deities make up a hierarchical pantheon, which is a reflection of the practitioners' view of the official imperial structure: under the rule of an emperor, there are high-ranking officers as well as numerous local officials. ${ }^{17}$ The outer and inner design of a typical temple resembles a government office, yamen, from the imperial time. This same government office appears in Cantonese operas as well as in television series and films about ancient stories. When worshippers of local religion seek a deity's blessing or assistance, they act in the same way people in the past were believed to do when they sought help from local government officials. Worshippers kneel, offer incense, food and paper products to the deity, much as they would have shown respect and offered gifts to officials in the government in the past.

Believers in local religion also think that all animals and natural landscapes have their individual spirits who can chose to help people with their supernatural powers. Despite their position at the bottom of the pantheon of gods and spirits, earth spirits can cause trouble for human beings if not taken care of and shown respect. In Hong Kong and Macau, people may worship old trees, rocks with special shapes and Earth Gods represented by rocks.

People also do their best to work with the supernatural power embedded in the natural landscape by following the system of fengshui, ${ }^{18}$ in which "air" (qi) and "dragon vein" (longmai) are very important. In fengshui, one determines the location and direction of the "dragon vein" or "air" in the natural landscape and can then capture the supernatural force in the natural environment by manipulating the positions and directions of houses, settlements and ancestral graves.

\footnotetext{
footnote continued

yu bianqian (The Development and Changes of Mazu Cult) (Taiwan: Taiwan Association for Religious Studies, forthcoming).

16. Liao Disheng (Liu Tik-sang), "Chuanjian xin miaoyu: shenmei de suzao yu xinzhong de canyu" ("The construction of a new temple: a shaman's initiation and the devotees' participation"), in Centre for Chinese Studies (ed.), Simiao yu minjian wenhua yantaohui lunwenji (Proceedings of Conference on Temples and Popular Culture) (Taiwan: Council for Cultural Planning and Development of the Executive Yuen, 1995), pp. 693-94; Tik-sang Liu, Becoming Marginal, pp. 180-192.

17. Wolf, "Gods, ghosts, and ancestors," p. 145.

18. See also Jack M. Potter, "Wind, water, bones, and souls: the religious world of the Cantonese peasant," Journal of Oriental Studies, Vol. 8 (1970), pp. 139-153.
} 


\section{Localized Deities}

Although people believe that the Jade Emperor occupies the highest position in the pantheon, he does not have the greatest power in solving people's problems. If a deity does not answer a devotee's requests, the devotee does not then go on to seek help from the Jade Emperor. In the eyes of the worshippers, different deities have different areas of expertise. Worshippers seek the god who will help them most in the area of difficulty; a minor Earth God might be the best choice.

Gods who share the same name may have different characteristics depending on the community. People accord local or ethnic distinctions to deities, ${ }^{19}$ perhaps turning a popular regional deity into a local patron god and using the patron deity's temple festival to unite community members and to define the community boundaries. ${ }^{20}$

In the literary tradition, the Tian Hou worshipped in Hong Kong and the Mazu worshipped in Taiwan and Fujian are the same deity. The Taiwan Mazu temples trace their genealogical roots to the ancestral temple in Fujian's Meizhou. ${ }^{21}$ In Hong Kong, however, the local communities are not concerned as to whether the deity they call Tian Hou has any relationship with the Mazu temple in Fujian or with Taiwan. Hong Kong worshippers do not trace the genealogical origin of their Tian Hou as do people in Taiwan. Tian Hou is considered to be a localized deity in Hong Kong, Macau and Guangdong. The common origin myth of a Tian Hou temple is that a deity image was found washed up on the beach, and a small shrine was built to house it. The small shrine was then rebuilt into a bigger one, and finally the deity became the community's patron god. People give their own Tian Hou a localized name, using the name of the place of the community as a prefix to the deity's name. Neighbouring Tian Hou goddesses are treated as sisters of their own deity and this sibling relationship justifies the worship of other Tian Hou deities in nearby communities. In this way, local religion becomes a reflection of the local social and political situation and the relationship among temple deities shows the relationship of neighbouring communities. ${ }^{22}$

The pantheon of local religion is an "open" system. New deities are introduced and others are ignored, forgotten and finally disappear from people's view. Also, the meaning and the role of a deity can be changed when society is undergoing transformation. Tian Hou became the most important deity along the South China coast when she was promoted by

19. John T. Myers, "Traditional Chinese religious practices in an urban-industrial setting: the example of Kwun Tong," in Ambrose Y.C. King and Rance P.L. Lee (eds.), Social Life and Development in Hong Kong (Hong Kong: Chinese University Press, 1981), pp. 284-86.

20. Watson, "Fighting with operas," pp. 150-51.

21. Steven P. Sangren, "Power and transcendence in the Ma Tsu pilgrimages of Taiwan," American Ethnologist, Vol. 20, No. 3 (1993), pp. 564-582.

22. Liao Disheng (Tik-sang Liu), "Difang rentong de suzao: Xianggang Tianhou chongbai de wenhua quanshi" ("The construction of local identity: the cultural interpretation of Tian Hou Cult in Hong Kong"), in Chi-tim Lai (ed.), Daojiao yu minjian zongjiao (Daoism and Popular Religion) (Hong Kong: Xuefeng wenhua shiye, 1999), pp. 118-134. 
the imperial state. ${ }^{23}$ Local societies do have a say in choosing their deities, though. They pick their own patron deities and neglect others. The fishing communities in Tai $\mathrm{O}$ and Tuen Mun are closely related through kinship and business ties, but they worship different patron deities. ${ }^{24}$ The fisherfolk in Tuen Mun worship Tian Hou, while the Tai O fisherfolk worship Yanghouwang (General Yang). After salt producers and merchants took control of the Tian Hou temple in Tai $\mathrm{O}$ in the early Qing period, the fisherfolk shifted their attention to Yanghouwang, whose temple was located at the outskirts of the local town, and adopted him as their patron deity. ${ }^{25}$

During the last few decades, new deities have been introduced in urban areas. Wong Tai $\operatorname{Sin}^{26}$ (Immortal Huang), a Daoist deity, was introduced in Hong Kong by some immigrants who were his devotees in Guangzhou, the capital of Guangdong province. ${ }^{27}$ A small shrine for Wong Tai Sin was established in 1921 in a squatter area where the immigrants lived. He has grown in popularity with the growth of the immigrant population. The area around the temple has been developed into large government housing projects, and the first project, ${ }^{28}$ completed in 1958, was named after the deity. In the early 1980s, Wong Tai Sin also became the name of an administrative district as well as the name of a station for Hong Kong's first subway, which brings in devotees from every corner of urban society.

The development of a new settlement and the introduction of the electric railway system helped change another little-known deity, Chegong (General Che), into a popular one. Chegong was originally a patron deity of a cluster of villages in Shatin. Shatin is now a town of about 628,000 residents, ${ }^{29}$ and the railway brings in devotees from all over Hong Kong. ${ }^{30}$ Recently, it has become a convention that the local leaders and government officials conduct a public divination to ask for fortune for Hong Kong people in the temple festival during the Lunar Chinese New Year.

23. James L. Watson, "Standardizing the gods: the promotion of T' ien Hou ('Empress of Heaven') along the South China coast, 960-1960," in Johnson, Nathan and Rawski, Popular Culture in Late Imperial China, pp. 292-324.

24. Eugene N. Anderson, The Floating World of Castle Peak Bay (Washington, DC: American Anthropological Association, 1970), pp. 160-61.

25. Liao and Zhang, Tai $O$.

26. The local form of romanization, Wong Tai Sin, is adopted in this article since it is an official place name in Hong Kong. The Mandarin form is Huangdaxian.

27. Graeme Lang and Lars Ragvald, "Upward mobility of a refugee god: Hong Kong's Huang Daxian," Stockholm Journal of East Asian Studies, No. 1 (1988), pp. 54-87; Graeme Lang and Lars Ragvald, The Rise of a Refugee God: Hong Kong's Wong Tai Sin (Hong Kong: Oxford University Press, 1993).

28. Currently, around 380,000 people reside in the government housing projects in the Wong Tai Sin district. See Home Affairs Department of the Government of the Hong Kong Special Administrative Region, "Wong Tai Sin: district highlights," in http:// www.districtcouncils.gov.hk/wts/english/welcome.htm, 15 December 2002.

29. See Home Affairs Department of the Government of the Hong Kong Special Administrative Region, "Special features of Sha Tin," in http://www.districtcouncils.gov.hk/ st/english/welcome.htm, 15 December 2002.

30. See also Graeme Lang, "Sacred power in the metropolis: shrines and temples in Hong Kong," in Grant Evans and Maria Tam (eds.), Hong Kong: The Anthropology of a Chinese Metropolis (Richmond: Curzon Press, 1997), p. 252. 
There are Yanghouwang, Wong Tai Sin and Chegong temples in other parts of Hong Kong, but they are not as popular as the three temples mentioned above.

\section{Religious Elements in a Household}

In addition to temples, there are altars for ancestors and patron deities in individual households. As different as temple festivals in various communities may be from one another, most household altars are quite similar. The tablets for ancestors, Master of the Site (dizhu), Heaven God (dangtian), Kitchen God (zaojun) and Door God (menguan) are commonly found in families practising local religion. Guanyin (Goddess of Mercy), Guandi (God of War), and Luzu (Immortal Lü) are the most popular deity images people set up at home in order to invite fortune. Incense sticks are offered daily to the ancestors and deities, and more elaborate offerings are presented during major Chinese festivals and family members' life cycle rituals. In these domestic rituals, known as "worshipping deities" (baishen), the ancestors are the first to be worshipped, then the patron deities in the house, and last, the Master of the Site and the Door God. The order in which the gods are worshipped shows their hierarchical relationship in the household.

A household's religious set-up is made up of deities from the lower rank of the hierarchical pantheon, with the Door God and the Master of the Site being the very lowest rank. ${ }^{31}$ This hierarchical pantheon links the household, from the bottom up, to the community and the state. In Wolf's reflection model, this is the people's ideal for the state's bureaucratic structure. $^{32}$

\section{Temple Festivals and Religious Organizations}

In Hong Kong and Macau, temple festivals are organized to celebrate the deities' birthdays. ${ }^{33}$ A temple festival is normally held for three or four days, with the deities' birthday falling in the middle of the celebration. Cantonese opera is the major activity and constitutes an offering to the deity. The opera is performed twice a day with a different four-hour play in the afternoon and evening. A large temporary stage is built in front of the temple, allowing the deity, on the altar inside the temple on the central axis, a good view. If the temporary stage has to be built away from the temple, a small travelling deity image must be carried to it. When this deity image is carried to the temporary stage, the procession is usually turned into a parade that ritually purifies "the deity's territory."

31. When people move away from their houses, many do not carry with them the deity images worshipped in their former houses. They rather leave those of lower rank gods in Earth God shrines or along the sides of a temple in the neighbourhood. People would acquire a new set of deity images for their new homes. This practice suggests that the deities belong to a special territory, where they are left by their worshippers.

32. Wolf, "Gods, ghosts, and ancestors."

33. See Chen Yande, "The folklore of local Mazu cult in Macau," pp. 136-140. 
A temporary shrine is set up at the opposite side of the stage for the travelling deity image, and the community members may worship the deity when they attend the opera performance.

Before the 1970s, the "flower-cannon catching" activity (qianghuapao) was a popular activity on the day of the deity's birthday. "Flower-cannons" (huapao), made of colourful paper decorations, each carrying a small deity image which was empowered with the deity's blessing, were distributed to devotees. ${ }^{34}$ Participants won a flower-cannon by catching a short, numbered stick shot out of a mini rocket. Whoever got a stick could keep the flower-cannon represented for a year, returning it the next year for someone else. To increase their chances, people formed flowercannon associations (huapaohui). Violent fights among rival groups at popular temple festivals were frequently reported. ${ }^{35}$ Subsequently, the police attempted to quell the violence by pushing organizers to distribute the flower-cannons by lottery.

Flower-cannon associations, large or small, are the popular form of participation in local religious events. People form associations based on religion, locality, ethnicity, gender or occupation. Most of the flowercannon associations stop operating after the temple festival and resume their activities at the next year's festival. Social networks built on their membership, however, are maintained throughout the year. When the colonial governments restricted the formation of local social organizations and limited local political participation, flower-cannon associations became one of the popular ways people organized themselves at the local level.

\section{Jiao Festival}

A Jiao festival is a large-scale communal ritual staged in order to pacify wandering ghosts, to purify the community's territory and to reach a cosmic renewal. There is no common set time for a Jiao festival. On Cheung Chau, an island in Hong Kong, it is held once a year, but in some places, it is arranged in either a 30- or 60-year interval. ${ }^{36}$ Most of the Jiao festivals are organized once every seven or ten years. The main Jiao ritual is usually held in the winter; a divination is conducted at the patron deity's temple at the beginning of the Chinese New Year in order to pick the ritual representatives among male community members for the forthcoming festival. A fortune-teller is hired to arrange the schedule of the Jiao activities believed to be beneficial to all participants. The fortune-

34. See also Liao Disheng (Tik-sang Liu), Xianggang Tianhou chongbai (The Cult of Tian Hou in Hong Kong) (Hong Kong: Joint Publishing (HK) Co. Ltd., 2000), pp. 79-95; Graham E. Johnson, "From rural committee to spirit medium cult: voluntary associations in the development of a Chinese town," Contributions to Asian Studies, Vol. 1, No. 1 (1971), pp. $141-42$.

35. Watson, "Fighting with operas," pp. 153-54; Liao Disheng, "From an alliance temple to a local cultural symbol."

36. Cai Zhixiang (Chi-cheung Choi), Da jiao: Xianggang de jieri he diyu shehui (Da Jiao: Festival and Local Societies in Hong Kong) (Hong Kong: Joint Publishing (HK) Co. Ltd., 2000), pp. 10-11. 
teller bases these calculations on the birth date and birth time of all the ritual representatives. Two smaller rituals to inform heaven of the Jiao festival are arranged in the middle of the year. For the major Jiao event, a huge temporary stage is constructed for the Daoist rituals and the Cantonese opera. Professional Daoist priests are hired to perform rituals - lasting several days - to pacify the wandering ghosts in the community. Everyone in the community eats only vegetarian foods during this period. After the Daoist ritual, a Cantonese opera is performed, also several days long, to celebrate the beginning of a new cosmic cycle. ${ }^{37}$ To mark this new start, people in the community begin to eat meat once more.

A Jiao festival is a communal event, and all the temple deities as well as the local Earth Gods are invited to participate. Daoist priests lead the ritual representatives in carrying the travelling images of the temple deities to the ritual site, while villagers send the paper tablets of the neighbourhood Earth Gods. These invited deities have the responsibility of monitoring the rituals and also partake in the fun of watching the Cantonese opera.

In many Jiao festivals, a "walking the sub-district" (xingxiang) ${ }^{38}$ ritual is arranged. The Daoist priests, ritual representatives and participating villagers walk over the community's territory. ${ }^{39}$ Community leaders go with the ritual troupe to visit their alliance villages. The Jiao festival is a large-scale religious and social activity. It requires the social and financial support of local organizations; it is an event expressing the unity of the community.

\section{Ancestral Halls and Deity Halls in Traditional Communities}

The powerful dominant lineages in Hong Kong's rural area have a long settlement history. They occupy fertile land that had been used as rice paddies for hundreds of years until the early 1970s. These lineages operate under the principle of patrilineal descent so that the male members are united under the symbol of their apical ancestor, who is worshipped in the ancestral hall. ${ }^{40}$ The lineage members register their names in the genealogy, thus justifying their right to claims on all lineage resources. The lineage's inalienable assets, usually in the form of land, are leased out to generate rental income. This supports regular ancestral worship activities as well as the maintenance of the ancestral hall. Until the early 1980s, a local security force (xunding) was organized by the

37. The arrangement of the opera performance in a Jiao festival is same as the ones in temple festivals. See also Ward, "Regional operas and their audiences."

38. In Cantonese, the name of the ritual has another homonymous meaning of "walking the incense."

39. See Watson, "Fighting with operas," pp. 150-51.

40. See Maurice Freedman, "Ancestor worship: two facets of the Chinese case," in Skinner, The Study of Chinese Society, pp. 296-312. 
lineage to protect its community. The area patrolled by this security force included the ritual and political territory. ${ }^{41}$

The ancestors of a lineage are represented in the form of tablets kept on a huge altar at the centre of the ancestral hall. In this hall, lineage members conduct ancestral worship, and meet to discuss issues of the lineage community. The big ancestral halls have a large courtyard for collective rituals and meetings, and a kitchen to prepare food for hundreds of people who attend the collective activities. ${ }^{42}$ The size and appearance of an ancestral hall shows the wealth and status of the lineage.

Lineage members call their first ancestor the "foundation-building ancestor" (kaijizu) or "carrying-pole-releasing ancestor" (luodanzu). He is recognized as the creator of the lineage, the one who bequeathed to his descendants the land where the lineage members now live. In the supernatural domain, the ancestors have the responsibility of protecting their descendants, and to help their descendants with the geomancy power transmitted through their graves. ${ }^{43}$

Under the patrilineal descent principle, only men can become members of their lineage and eventually become ancestors. The ancestors are the icons uniting all lineage members. The male members' life cycle rituals are conducted in the ancestral hall before the ancestors. During the first lunar month of the lunar year, the "lantern lighting" rituals (diandeng) are arranged at the ancestral hall for families of newborn babies. At a wedding, the new couple and the groom's father must go to the ancestral hall to worship the ancestors. Although death rituals are not conducted in the ancestral hall, ${ }^{44}$ the souls of the dead are believed to join the other ancestors' souls in the collective tablet in the ancestral hall. ${ }^{45}$

Birth and marriage rituals are very important for newborn sons and married-in wives in order to confirm their inclusion in the lineage. ${ }^{46}$ The ancestors are not only a religious symbol, but also a symbol of political unity: an extremely important symbol of local politics, religion and economy.

For several centuries, the fertile plains in Hong Kong's New Territories have been occupied by big lineages. Latecomers could only settle along the coast and in mountainous areas not suitable for paddy rice culti-

41. Hugh D. R. Baker, A Chinese Lineage Village: Sheung Shui (Stanford: Stanford University Press, 1968), pp. 79-83; Rubie S. Watson, Inequality among Brothers: Class and Kinship in South China (Cambridge: Cambridge University Press, 1985), pp. 94-97.

42. James L. Watson, "From the common pot: feasting with equals in Chinese society," Anthropos, No. 82 (1982), pp. 389-401.

43. See Watson, "Remembering the dead," p. 207.

44. James L. Watson, "Of flesh and bones: the management of death pollution in Cantonese society," in Maurice Bloch and Jonathan Parry (eds.), Death and the Regeneration of Life (London: Cambridge University Press, 1982), pp. 155-186.

45. See Watson, "Remembering the dead," p. 208.

46. A daughter does not have the right to inherit her father or the lineage's property, but her parents would prepare her a dowry for her wedding. After a woman marries, she has the right to be buried in her husband's lineage's territory and has a position in her son's ancestral altar when she dies. For the discussion of women's status in a lineage in Hong Kong's New Territories see Rubie S. Watson, "The named and the nameless: gender and kinship in the Hong Kong region, 1900-1940," American Ethnologist, Vol. 13, No. 4 (1986), pp. 619-631. 
vation. ${ }^{47}$ Working hard to survive with limited local resources and political power, these latecomers were not able to develop into dominant lineages. Some managed to form small single-lineage villages, ${ }^{48}$ with their own ancestral halls and lineage worship activities. Some of the surname groups formed multi-surname villages: villages consisting of several surname groups. ${ }^{49}$ The surname groups have their own small ancestral halls, but share a common temple, known as the deity hall (shenting), which is the centre for the village's religious activities. Some of the ritual activities which are normally performed in the ancestral halls have been moved and are now conducted in the common temple. The temple has become the centre of community activities for the different surname groups in a single village.

\section{Alliance Temples}

In imperial times, state power rarely reached China's southern edge. Local societies in Hong Kong's New Territories had to take care of their own security matters and resolve their own conflicts. Local politics were controlled by the big lineages, whose members firmly controlled local resources and defended their territories. Small villages had to depend on these powerful lineages for protection. To maintain their power, the large lineages solicited the support of their satellite villages by forming a regional alliance, yue (in Cantonese, yuek). ${ }^{50} \mathrm{In}$ areas where there was no powerful dominant lineage, villages joined together in a similar way in order to protect themselves against aggressive neighbours. These regional alliances united the lineages and villages within a particular territory sharing a common irrigation system, as Brim argues. ${ }^{51}$

Rather than choosing one lineage's ancestor to unite people with different surnames, people who formed a regional alliance would choose a patron deity as a symbol of their unity. The deity's temple became the place where yue members met for religious activities and political discussions. ${ }^{52}$ Yue became the local political units involved in discussing disputes over land and water rights, something which sometimes resulted in local battles. ${ }^{53}$ Those killed in the battles were worshipped in the

47. See Nicole Constable, Christian Souls and Chinese Spirits: A Hakka Community in Hong Kong (Berkeley: University of California Press, 1994), pp. 40-42; Tik-sang Liu, Becoming Marginal, pp. 12-20.

48. James L. Watson, "Hereditary tenancy and corporate landlordism in traditional China: a case study," Modern Asian Studies, Vol. 11, No. 2 (1977), pp. 161-182.

49. Judith Stauch, "Community and kinship in southeastern China: the view from the multilineage village of Hong Kong," Journal of Asian Studies, Vol. 43, No. 1 (1983), pp. $21-50$.

50. David Faure, The Structure of Chinese Rural Society: Lineage and Village in the Eastern New Territories, Hong Kong (New York: Oxford University Press, 1986), pp. $100-127$.

51. John Brim, "Village alliance temples in Hong Kong," in Wolf, Religion and Ritual in Chinese Society, pp. 93-103; see also Patrick Hase, "The alliance of ten: settlement and politics in the Sha Tau Kok area," in Faure and Siu, Down to Earth, pp. 123-160.

52. Brim, "Village alliance temples in Hong Kong."

53. See Watson, "Fighting with operas," pp. 148-49; Liao Disheng, "From an alliance temple to a local cultural symbol." 
alliance temples. The heroes' altars are kept in a side chamber called Hero Hall. These kinds of altars are found in the Guanyin temple in Pat Heung, the Tian Hou temple in Shap Pat Heung, the Tian Hou temple in Lam Tsuen and the Tian Hou temple in Tsuen Wan.

Annual festivals at the alliance temples are events where the people of the member villages within the yue territory meet and express yue unity as well as define territorial borders. Jiao festivals take place regularly in order to pacify wandering ghosts, to renew community and the universe, and to thank the deities for protecting the community. ${ }^{54}$ The alliance temple deity is the chief deity in the Jiao festivals. Participation of the member villages as well as the parade taking place during the Jiao festival are important acts in defining the community and the territorial boundaries.

\section{Religious Activities in the Urban Setting}

There are many old temples in the urban area, but this community's involvement in temple activities is not as great as that of the rural community. Many people would say that this is because the rapidly changing urban area and the highly mobile population makes it difficult to maintain a neighbourhood and a community identity. Another reason is probably the Hong Kong government's control of major temples in the urban area, discussed below. Urban people do continue to participate in religious activities, however.

During the last few decades, the size of Hong Kong's population has been affected by the social and political situation in China. Immigrants from China formed a large part of Hong Kong's population, especially during the 1950s and 1960s when there was political turmoil in China. Most of these immigrants first lived as squatters and then gradually moved to better and more secure areas when they had enough money to do so. It is very difficult for local religious activities to be established in a highly congested urban environment where there is such a shortage of space. In some early squatter settlements and government housing projects, newcomers established local altars or shrines housed in very simple structures. These have become hubs for local religious activities, as temple festivals were an opportunity for new immigrants to nurture their local identity. In the 1970 s, for example, many shrines were established in many immigrant communities in Kwun Tong, Sau Mau Ping, Ngau Tau Kok, Chai Wan, Lok Fu and Tsuen Wan. ${ }^{55}$ However, these local communities have to struggle with government officials in order to maintain the permanent shrines in their areas, and successful cases are very limited. Many of these temples are facing removal as the original communities have been resettled and the government is beginning to develop the land on which they once lived.

54. Chi-cheung Choi, "Reinforcing ethnicity"; Faure, The Structure of Chinese Rural Society, pp. 80-86.

55. Myers, "Traditional Chinese religious practices in an urban-industrial setting," pp. 275-288. 
Like people in the country, people in urban settings feel that they must attend to wandering ghosts in the supernatural realm. In traditional communities, this is done by staging Jiao festivals. In the urban setting, people organize the Yulan, or Hungry Ghost, festival in the seventh lunar month. Many of these festivals are initiated and organized by the Chaozhou immigrants, but local residents and shopkeepers also support the events. ${ }^{56}$ Many of the festivals take place in government housing projects where the immigrants live.

For a Yulan festival, a temporary stage is constructed in an open space, usually a basketball court or football field. To express their (sub)ethnic identity, Chaozhou Daoist priests are hired to perform the ritual for the ghosts, and a Chaozhou opera performance is arranged. ${ }^{57}$ Recently, there has been a shortage of Chaozhou Daoist priests and opera troupes in Hong Kong, so organizers have taken to hiring priests and opera troupes from their home villages in Chaozhou.

The relationship between immigrants and their home villages is important when looking at local religious activities in the urban context. Although there are not many communal religious activities in the urban area, some immigrants participate in communal religious events in their home communities. The immigrants have their relatives, friends, lineage organizations, ancestral hall and ancestral graves in their home villages. When they conduct their rituals or ancestral worship at home, the rituals are not only just an urban event, but are directly tied to their native places.

\section{Other Popular Beliefs}

Many different schools of thought have grown up to explain the impact of the natural landscape on human settlements, and the methods of discovering the sacred force. The basic assumption is that the geomantic power can benefit all living things, but that the destruction of the natural landscape will generate "killing air" $(\text { shaqi })^{58}$ that people must avoid. ${ }^{59}$ Geomantic power is like a hidden treasure waiting for people to discover. In an anthropological sense, geomancy is magic; the acquisition of geomantic force has nothing to do with the morality of the discoverer. Anyone can hire a good fengshui master to identify the location of the force. One captures the beneficial power and avoids the harmful forces by manipulating the setting and direction of a building or the decorations

56. See Hang-shi Chiu, "Yaumatei and the Yu Lan festival," in P.H. Hase (ed), In the Heart of the Metropolis: Yaumatei and its People (Hong Kong: Joint Publishing (HK) Co. Ltd., 1999), pp. 150-59.

57. See Chen Shouren (Sau-yan Chan), Shengongxi zai Xianggang: Yueju, Chaoju ji Fulaoju (Sacred Operas in Hong Kong: Guangdong, Chaozhou, and Fulao Operas) (Hong Kong: Joint Publication (HK) Co. Ltd., 1996), pp. 29-32; Myers, "Traditional Chinese religious practices in an urban-industrial setting," p. 286.

58. The killing air could also be generated by a corpse when the flesh decomposed. Watson, "Of flesh and bones," pp. 158-59.

59. James Hayes, The Rural Communities of Hong Kong: Studies and Themes (Hong Kong: Oxford University Press, 1983), pp. 153-55. 
inside a building. If an ancestor is buried in an ideal fengshui location, the ancestor's bones can transmit beneficial power to his descendants. ${ }^{60}$

In the country, the geomantic set-up of ancestral halls and ancestral graves is believed to affect the prosperity of the lineage, while the geomancy of a temple influences its supporting community. Although urbanites do not unite around ancestral halls, ancestral graves or temples, geomancy is still very popular. This belief that there are always beneficial and harmful forces affecting every aspect of people's daily life causes people to manipulate the interior design and decoration of their apartments in order to capture the geomancy force and expel evil forces. ${ }^{61}$ Geomantic validations are often available when a new housing project is for sale.

Geomancy is a form of belief constituting the foundation of the local religion in South China. Interestingly, in an anthropological sense, the religious significance of fengshui has been turned into a language explaining human inequality and conflict. In the New Territories, fengshui explains the economic differences among branches of families who trace their descent from a common ancestor. The supernatural explanation of wealth eliminates possible conflicts between the rich and the poor. $^{62}$

Fengshui is also a weapon used by local people to confront government or land developers when they destroy the natural landscape for construction projects. ${ }^{63}$ It has become a resource used to halt the development or to negotiate for compensation. When the government compensates a community for a development project in which the natural landscape is destroyed, it is often set aside for a ritual to regain balance in the natural environment. ${ }^{64}$

In the city, the real estate business is very involved in fengshui. When a new housing project is ready to go on the market, developers release information showing that the building has good fengshui, much better than other buildings for sale. Like people in rural areas, urbanites also use fengshui to express and manipulate human conflicts. Once in a while, there is news of fighting among neighbours over fengshui conflicts.

Fengshui even became an issue on the state level during Hong Kong's return to China in 1997. There was a fengshui conflict between the Governor's House and the Bank of China building, a 70-storey skyscraper designed by the famous architect I.M. Pei. The triangular shape of the building was seen to be like a knife, with the sharp edge aimed at

60. See Watson, "Remembering the dead."

61. See also Charles F. Emmons, "Hong Kong's feng shui: popular magic in a modern urban setting," Journal of Popular Culture, Vol. 26, No. 1 (1992), pp. 39-49.

62. Watson, "Remembering the dead," pp. 214-15.

63. See also Hayes, The Rural Communities of Hong Kong, pp. 146-152; Sidney C. H. Cheung, "Land use and fung-shui: negotiation in the New Territories, Hong Kong," Cultural Survival Quarterly, Vol. 25, No. 2 (2001), pp. 70-71.

64. James Hayes, "Local reactions to the disturbance of 'fung shui' on Tsing Yi Island, Hong Kong, September 1977-March 1978," Journal of the Hong Kong Branch of the Royal Asiatic Society, Vol. 19 (1979), pp. 213-16. 
the Governor's House, causing difficulties for the British side in the conflictual negotiations over Hong Kong's future. ${ }^{65}$ The story goes that the British wisely planted a willow tree in the Governor's House garden between the two buildings. The branches of the willow tree were supposed to repel the evil effect of the bank building, solving the problem.

The Bank of China Building in Macau was completed in 1991, but it was built facing the Ferreira do Amaral Equestrian Monument, a five-ton bronze statue of "one of the most outstanding governors of Macau." In 1992, this monument was shipped back to Portugal to symbolize the decolonization process. It was popularly believed that the monument had really been removed because it was creating a harmful geomantic force against the Bank of China building. ${ }^{66}$

Beliefs about language also play a strong part in people's daily lives. During major festivals and life cycle rituals, people always want to hear auspicious remarks, which are believed to affect their fortune. If a remark has a negative implication, this could adversely affect one's future. In present-day Hong Kong, manipulating the meaning of numbers is also popular. The homonyms of some numbers are believed to bring the users good or bad luck. People want to have auspicious numbers for their home addresses, for the floor of the building they live in, for their licence plates and for their telephone numbers. The number "three" sounds like the word for "alive," and the number "eight" sounds like "prosperity," while the number "four" is avoided as it sounds like "death." Even if one does not completely believe the importance of obtaining some numbers and avoiding others, having good numbers shows a person's status, as it often takes substantial funds to get them.

\section{Links to the Other World}

Deities, ancestors and ghosts live in an invisible supernatural world which coexists with the natural world, allowing spirits to be closely involved in human matters. Once a human being leaves the natural world, people believe he or she enters the supernatural world as either a spirit or a ghost. All supernatural beings have the ability to affect human matters in the natural world.

The belief is that after death, people who have committed many faults during their lives are sent to hell to be tried. The dead people's children and relatives must hire specialists to conduct rituals in order to reduce the sufferings of the deceased in hell. Rituals are considered "virtue and merits" (gongde), and can counteract wrongdoing. ${ }^{67}$ Spirits who do not get any of this attention become dangerous and can disturb people in the

65. Christina Miu-bing Cheng, "Resurgent Chinese power in postmodern disguise: the new Bank of China buildings in Hong Kong and Macau," in Evans and Tam, Hong Kong: The Anthropology of a Chinese Metropolis, pp. 102-123.

66. Ibid.

67. For the discussion of the Buddhist's concept of gongde, see Holmes Welch, The Practice of Chinese Buddhism, 1900-1950 (Cambridge, MA: Harvard University Press, 1967), pp. 377-382. 
natural world. Responsible descendants should worship their ancestors and provide them with sufficient paper and food offerings to deter them from turning into wild ghosts. ${ }^{68}$ When the deceased has accumulated enough virtue and merits from living a good life and having been tended properly by descendants, he or she will go back to the natural world and be born a human being once more. The two worlds are linked by ghosts and by reborn human beings. Buddhist rituals are often arranged for dead people, as the Buddhist belief in rebirth fits the people's expectations. ${ }^{69}$

When people are in need of something, they seek help from the spirits, expressing their needs to the deities through simple rituals. Some people believe that a better result will be attained if the ritual is conducted by a specialist. Professional Daoist priests, known as nanwu (nam mo in Cantonese) are hired for the most important festivals or major life cycle rituals. These Daoist priests maintain their religious traditions by transferring their knowledge of rituals and of ritual techniques to apprentices, as well as making available standardized handbooks on rituals. Using standardized rituals, the Daoist priests deliver the clients' messages and ritual offerings to the supernatural world. The priests claim that they have to follow their traditions in order to conduct the rituals, but the local people who are their clients also demand they incorporate local practices, which have been passed down from their ancestors. It is common to see the "great" (the Daoist) and the "little" (the local) traditions presented in local religious rituals. Each ritual expresses the identity of the local community as well as the relationship between the local society and the state. In these rituals, the path of communication is a one-way street: the ritual specialists cannot read what the spirits may want to say to the people asking for their help.

In order to hear what the spirits have to say, some clients seek help from professional shamans, known locally as "rice-asking women" (wenmipo). The shamans go into a trance, and it is believed that they are possessed by spirits who can then communicate directly with those in the natural world. ${ }^{70}$ In this way, clients can understand the needs of the spirits and take care of them, thus resolving their own problems which they believe have been caused by unhappy spirits.

\section{Sacred Time}

In local religion, time is regarded as a supernatural element to which attention must be paid. The popular almanac, tongsheng, is used to help pick the most auspicious timing for ritual activities. This almanac pro-

68. To express care for their ancestors, people not only offer traditional paper items, but also paper products in shape of items existing in the ordinary daily life, such as cellular phones, watches, sports shoes, houses, airplanes, cars, yachts or even domestic helpers. See Janet Lee Scott, "Traditional values and modern meanings in the paper offering industry of Hong Kong," in Evans and Tam, Hong Kong: The Anthropology of a Chinese Metropolis, pp. 223-241.

69. For the discussion of the Buddhist's concept of rebirth, see Welch, The Practice of Chinese Buddhism, pp. 179-181.

70. See Liao Disheng, "The construction of a new temple"; Potter, "Cantonese shamanism." 
vides guidance based on the lunar calendar about the best and worst times of every day and every hour to perform various activities. The timing of a ritual, however, is not determined simply by the almanac; specialists are also hired. Based on the birth dates and times of the participants in the ritual or festival, an ideal timing is calculated in order to avoid evil impact and have the most auspicious results. For example, the rites included in a wedding are determined by the couple's birth dates and times. These rituals are believed to affect the life of the couple after the wedding, and are therefore very important and must be carefully timed. For a Jiao festival, the entire schedule of events is determined by calculations using the birth dates and times of all the participants in the ritual. Thus, the life cycles of individuals are linked to the major communal rituals.

People usually arrange communal temple festivals during the deities' birthdays. In order to achieve the best result, people often pick a particular time of day to begin the festival. For the Tian Hou festival at Yuen Long Shap Pat Heung, the organizers worship the deity on the eve of the festival, at midnight. They believe that this is the beginning of the festival. Most communities celebrate the festival at midday on the 23rd day of the third lunar month.

\section{A Tradition of Opposition to Local Religion}

The Chinese Confucian elite has a long tradition of disregarding local religions; "gods" and "ghosts" are considered inappropriate topics for discussion. Starting with the May Fourth movement, local religion in China was considerably beaten down. Considered "feudal superstition" and blamed for China's poverty and backwardness, local religious practices were criticized for not being scientific as they relied on divination to solve problems. Local religions were said to nurture people's selfish and utilitarian attitudes which were now obstacles to the industrialization and modernization of China. ${ }^{71}$

The educated elite in Hong Kong inherited some of this anti-local religious tradition and tend to ignore the existence of local religion. The school curriculum, for example, pushes the anti-local religion tradition, aided and abetted by the prevalence of Christian organizations in Hong Kong's school system. A large number of Hong Kong schools are run by volunteer associations with the government subsidizing their operational costs; many of these organizations are Protestant and Roman Catholic, and because of their own agendas, they are not eager to promote local religion. $^{72}$

71. See also Myron L. Cohen, "Being Chinese: the peripheralization of traditional identity," Daedalus, Vol. 120, No. 2 (1991), pp. 127-29; Shuk-wah Poon, "Refashioning popular religion: common people and the state in Republican Guangzhou, 1911-1937," PhD dissertation, Hong Kong University of Science and Technology, 2001, pp. 80-113.

72. In 2001, the Protestant organizations operated 609 schools and kindergartens, while the Roman Catholic organizations operated 327 schools and kindergartens in Hong Kong. Hong Kong Government, Hong Kong 2001, pp. 393-98. 


\section{Co-optation and Suppression}

There was no formal political participation at the local level in Hong Kong until 1982, when the District Board system was introduced allowing a general election of local political leaders. In the New Territories, there has been a Rural Committee system since the 1950s. Villagers elect representatives on to the Rural Committees which make suggestions to the government on local issues. In the colonial establishment, the District Board councillors or village representatives did not have much political influence on government decisions, the office being instead a symbol of social status. Local religious activities are also events where local leaders can show off their organizational and political skills.

The temple and Jiao festivals are communal events requiring the co-ordination and participation of community members. Each festival attracts tens of thousands of people. These events give local leaders the opportunity to exercise their leadership and management skills. Government officials fully understand the situation and are willing to participate in the ceremonies in order to endorse the local leaders' positions. There is always a presentation in religious events where government officials, guests and chief donors are publicly presented with gifts.

The presence of the government officials sends a clear signal of their power in the local community, and they are also endorsing the local leaders' positions. Most local leaders do not have a formal position in the local political structure, however, as they are co-opted into government politics by the officials' presence in local events.

Community members organize themselves into religious organizations in order to participate in temple festivals and in flower-cannon activities. The police require all religious organizations to apply for permission in order to organize a lion or dragon dance troupe to appear at a festival. Lighting firecrackers had always been popular celebratory activity, but after the riots of 1968 the government banned the use of fireworks on any occasion, although villagers do not really observe the regulation when they conduct major rituals. The government further suppressed any violence that might erupt during flower-cannon activities by encouraging their distribution by lottery.

\section{Resources for the Heritage and Tourism Industry}

Temple festivals and the like have recently become tourist draws in Hong Kong and Macau. A 20-metre marble Mazu (Tian Hou) statue, ${ }^{73}$ a duplicate of the one in Mazu's homeland in China, was built on Macau's Coloane Island in 1998. In 2001, the Macau government organized a Mazu festival to promote tourism. This ritual, officiated by the Chief Executive of Macau, took place on the hill where the Mazu statue stands. A troupe of performers was brought in from Fujian to perform the

73. The official record of the height of the statue is 19.99 metres. It was reported to be the tallest Mazu statue in the world. Wenhui bao (Wenhui Daily), 29 October 1998. 
“official" Mazu rite, and pilgrims from Taiwan's Dajia Zhenlangong ${ }^{74}$ also participated by shipping their ritual possession decorations and the travelling Mazu deity to the festival.

The Hong Kong government does not play an active role in promoting local religious activities. Similar to Macau, however, tourism has been one of the reasons the government is interested in regulating religious activities. The most successful case in this respect is the conversion into touristic and sporting events of local dragon boat races held during the Duanwu festival. Local dragon boats race to have the honour of representing their communities in the International Dragon Boat Race, the winners of which will represent Hong Kong in other countries. Organizers successfully eliminated the religious element of this event, which was originally about pacifying wandering ghosts in the water. ${ }^{75}$

In recent years, many religious buildings have been declared to be part of Hong Kong's heritage. Many temples and ancestral halls, identified as historical buildings, have been renovated or preserved. The Hong Kong government provides funding and guidance in the renovation projects. ${ }^{76}$ The function of these religious buildings changes, however, after renovation, as the religious centre is turned into a museum and is open to the public. The religious buildings in Ping Shan and Lung Yeuk Tau are featured under two "Heritage Trails," 77 tours for the benefit of tourists, and these formerly religious buildings have become a cultural resource for the Hong Kong tourist industry. ${ }^{78}$

\section{Conclusion}

In the case of Hong Kong and Macau, local religion does not exist passively, but actively organizes local society. It is impossible to separate local religious activities from people's daily lives. Religious practices constitute the foundations of local social organizations; they are the means with which local society is organized, local people are mobilized, communal activities are co-ordinated and people are prepared for their various stages in life.

People organize religious activities for ancestors, gods and ghosts. Ancestral worship gives people a way to organize themselves according to the patrilineal descent principle. An apical ancestor binds his offspring's family to form a lineage, the most popular form of social

74. The same organization organizes the famous annual Mazu pilgrimage in Taiwan. For details see Meiying Huang, Taiwan Mazu de xianghuo yu yishi (The Incense and Rituals of Taiwan Mazu) (Taiwan: Zili wanbaoshe wenhua chubanbu, 1994).

75. See Yoshiro Shiratori (ed.), The Dragon Boat Festival in Hong Kong (Tokyo: Ethnohistorical Research Project, Sophia University, 1985).

76. In the last two years, the renovation of a temple and of an ancestral hall each won an award from UNESCO for local involvement in the preservation of local heritage.

77. See also Sidney C. H. Cheung, "The meanings of a heritage trail in Hong Kong," Annals of Tourism Research, Vol. 26, No. 3 (1999), pp. 570-588.

78. See Rubie S. Watson and James L. Watson, "From hall of worship to tourist center: an ancestral hall in Hong Kong's New Territories," Cultural Survival Quarterly, Vol. 21, No. 1 (1997), pp. 33-35. 
organization in South China. All the lineage members are linked through the worship of their common ancestor, and their common assets are maintained under the name of the ancestor.

In an area where more than one surname group resides, a patron deity can act as a symbol to tie the different groups together. Once a stateapproved deity is picked for worship, the local society has a legitimate reason to organize itself into social groups and gather together for festivals at a temple. The deity's birthday celebration is an event which mobilizes people, forms local social organizations and expresses unity. People also mobilize to pacify wandering ghosts, who are dangerous spirits that need to be dealt with. To do this, people organize Jiao festivals in the New Territories and Yulan festivals in the urban areas.

Gods, ghosts and ancestors are religious and philosophical concepts that are sanctioned by the state and by the educated elite. To maintain state authority over religious unity, the meaning of these concepts are tightly controlled and defined solely by state-approved philosophers and religions. However, they may not have any local meaning. There has always been a tendency for local societies to co-opt the concepts and make them part of their own cultures. In this localization process, geomancy plays a very important role. It explains how the local environment empowers deities, ancestors and even ghosts. It gives reasons for why one particular temple deity is more powerful than another, and how an ancestral grave can benefit the lineage members. Geomancy can also work in the opposite way, interacting with dangerous ghosts to harm local residents. Local people who believe in geomancy link the natural world to the supernatural world and connect the supernatural power of animatism with animated spirits.

The magical nature of geomancy gives it a "scientific" outlook, which gives it justification in the modern world. The assumption that it is scientific allows people to reject the attack of local religion as being superstition. Geomancy has been incorporated into the design of modern architecture, playing a part in explaining harmony as well as conflict between members of the hegemonic states in two colonies.

In the process of rapid urbanization, the size of supporting communities of communal religious activities is shrinking. Some local societies are having difficulty in raising funds for frequent religious celebrations. A few of them received support from their emigrant members who came home seeking their native place identity. The expressive aspects of local religion are promoted, but always in the name of tourism or cultural preservation. The religious and social significance of temples and ancestral halls are overshadowed by emphasis on their importance to the region's cultural heritage. Religious buildings are being treated as museums, while religious rituals are regarded as traditional performances.

Interestingly, these recently recognized elements of Hong Kong's cultural heritage have become the "authentic models" for South China's local societies to replicate. On the other hand, genealogical links are being established between temples in the mainland on one side and 
temples in Hong Kong and Macau on the other. In the near future, local religion will become a significant cultural linkage binding the three places within the "one country two systems." 